\title{
Air Quality Status of Respirable Particulate Levels at Selected Traffic Junctions along the Section of Lateral Highway in Hyderabad
}

\author{
Manda Karunakar Reddy, Mareddy Sumathi
}

NEERI Zonal Laboratory, Hyderabad, India.

Email: \{neeri_h, apchzl\}@yahoo.com

Received February $9^{\text {th }}, 2011$; revised April 19 $9^{\text {th }}, 2011$; accepted June $7^{\text {th }}, 2011$.

\begin{abstract}
The aerodynamic diameter of an air borne particle is the key property in determining its respiratory deposition. The study aim to assess $P M_{2.5}$ level and its size distribution at 5 traffic junctions located along the lateral highway connected to $\mathrm{NH}-202$. A cascade impactor has been used to measure the size function range of $P M_{2.5}$ apart from $P M_{10}$ of atmospheric dust particles in air being $P M_{2.5}$ is concern with respect to effect on human health and is able to tend deeply into the respiratory tract reaching the lungs. It is observed that weight $\%$ of $P M_{2.5}$ values are in the range of $40 \%-60 \%$ of $P M_{10}$ and few values of $P M_{2.5}$ are exceeding the standards prescribed by CPCB. It is concluded that free flow of traffic is main concern and maintenance of road should be carried out during low traffic hours.
\end{abstract}

Keywords: $P M_{2.5}$, Air Borne Particle, Traffic, Respirable Dust, Particle Size

\section{Introduction and Methods}

Several studies indicates that respirable particulate matter can have a severe effect of human health specially $\mathrm{PM}_{2.5}$. There are strong indications that the number of particles may be more relevant for human health effects than the particle mass [1]. However the particles contribute very little to the total suspended mass and these are not taken into account by emission or air quality standards related to particle mass, even though they may have severe health effects.

Particulate matter is the term used for a mixture of solid particles and liquid droplets found in the air. $\mathrm{PM}_{2.5}$ refers to particulate matter that is $2.5 \mu \mathrm{m}$ or smaller in size. 2.5 micrometers is approximately $1 / 30$ the size of a human hair on average [2]. Particulate matter with aerodynamic diameter (unit density sphere) of $2 \mu \mathrm{m}$ is $90 \%$ respirable whereas $2.5 \mu \mathrm{m}$ is $75 \%$ respirable [3].

Respirable dust refers to those dust particles that are small enough to penetrate the nose and upper respiratory system and deep in to the lungs. Particles that penetrate deep into the respiratory system are generally beyond the body's natural clearance mechanism of cilia and mucus and are likely to be retained.

The sources of $\mathrm{PM}_{2.5}$ include fuel combustion from automobiles, power plants, wood burning, industrial processes/operation units etc. However size distribution of particulate matter through industrial process depends on the process, control equipment and its working condition [4]. In urban area $\mathrm{PM}_{2.5}$ emission is mainly from onroad vehicles i.e., two wheelers, three wheelers and four wheelers of light and heavy vehicles [5]. These fine particles are also formed in the atmosphere when gases such as sulfur dioxide, nitrogen oxides, and volatile organic compounds (all of which are also products of fuel combustion) are transformed in the air by chemical reactions.

Fine particles are of concern because they are risk to both human health and the environment. Because these particles so small they can able to travel deeply into the respiratory tract, reaching the lungs. Exposure to fine particles can cause short-term health effects such as eye, nose, throat and lung irritation, coughing, sneezing, runny nose and shortness of breath. Exposure to fine particles can also affect lung function and worsen medical conditions such as asthma and heart disease. Scientific studies have linked increases in daily $\mathrm{PM}_{2.5}$ exposure with increased respiratory and cardiovascular hospital admissions, emergency department visits and deaths. Studies also suggest that long term exposure to fine particulate matter may be associated with increased rates of chronic bronchitis, reduced lung function and increased mortality 
from lung cancer and heart disease. People with breathing and heart problems, children and the elderly may be particularly sensitive to $\mathrm{PM}_{2.5}$. Studies on particle mass concentration $\left(\mathrm{PM}_{10} \& \mathrm{PM}_{2.5}\right)$ indicate that for particle mass there is no threshold in particle concentration below which health would not be jeoparadised. [6].

Deposition velocity on the skin found to be $7.4 \pm 1.1 \times$ $10^{-4} \mathrm{~m} / \mathrm{s}$ for the $0.5 \mu \mathrm{m}$, whereas $57 \pm 14 \times 10^{-4} \mathrm{~m} / \mathrm{s}$ for the $2.5 \mu \mathrm{m}$ particles [7]. The amount of pollutants deposited on the skin of dressed person is more than an order of magnitude longer than the amount deposited in the lungs and that skin deposition is an important pathway for toxics that can penetrate through the skin.

As per previous study, levels of $\mathrm{PM}_{2.5}$ at several locations at Delhi, India have reported to be in the range of $78-109 \mu \mathrm{g} / \mathrm{m}^{3}$ [8]. The Mean $\mathrm{PM}_{2.5}$ concentration for the background mixed/traffic industrial site in Chennai (India) were 35,46 and $54 \mu \mathrm{g} / \mathrm{m}^{3}$ respectively and ratio between $\mathrm{PM}_{2.5}$ to $\mathrm{PM}_{10}$ was about 0.5 at all the three sites during 2002 - 2003 [9]. Measurement were carried out for one year at two sites in Mumbai city, average values of $\mathrm{PM}_{2.5}$ and $\mathrm{PM}_{10}$ were 43 and $61 \mu \mathrm{g} / \mathrm{m}^{3}$ at ambient site and at kerbsite 69 and $90 \mu \mathrm{g} / \mathrm{m}^{3}$ respectively. The results also indicate that on an average, ratio of $\mathrm{PM}_{2.5}$ and $\mathrm{PM}_{10}$ was 0.68 and 0.7 at ambient and Kerbsite respectively [10]. OAQPS (USEPA) paper indicate that annual mean concentration of $\mathrm{PM}_{2.5}$ were above $20 \mu \mathrm{g} / \mathrm{m}^{3}$ in several major urban areas through out the eastern US including Pittsburg, Cleveland, Atlanta, Chicago, St. Louis and in Los Angels and the central valley of California. Values in the $40-65 \mu \mathrm{g} / \mathrm{m}^{3}$ range were more common in the eastern U.S and on the west coast, but relatively rare in the central and western mountain regions [11]. Recently it has become mandatory to monitor $\mathrm{PM}_{2.5}$ levels (India). CPCB (India) prescribed air quality standard on 24 hrly average is $60 \mu \mathrm{g} / \mathrm{m}^{3}$ and for annual average is $40 \mu \mathrm{g} / \mathrm{m}^{3}$ [12]. Whereas EPA prescribed standard for $\mathrm{PM}_{2.5}$ on 24 hrly average is $35 \mu \mathrm{g} / \mathrm{m}^{3}$ [13]. The present study has made an attempt to monitor $\mathrm{PM}_{2.5}$ along the lateral highway connected to NH-202 at five locations from Secunderabad to Uppal X road.

\section{Study Area}

Hyderabad is one of the fastest growing cities in the country with a potential to become cyber capital of India. It is located on the Southern Central region and it is almost in the middle of India.

Hyderabad is one of the metropolises of India with a population of 40.1 lakhs as per 2011 census [14]. The city is witnessing a rapid expansion, industrial boom, increased trade opportunities coupled with high population growth rate (decadal rate $40 \%$ ) accelerated due to migra- tion from rural areas. Hyderabad city has hot steppe type climate with average temperature ranges between $40^{\circ} \mathrm{C}$ \& $43^{\circ} \mathrm{C}$ in summer and $13^{\circ} \mathrm{C} \& 17^{\circ} \mathrm{C}$ in winter and humidity ranging between $25 \%$ and $80 \%$ respectively. The city has Altitude of $536 \mathrm{~m}$ above mean sea level, monsoon and post-monsoon conditions prevail from June to December and the average annual rainfall is recorded about $89 \mathrm{~cm}$.

About $10 \mathrm{~km}$ section of road is covered for sampling. Monitoring was carried out at selected 5 different traffic junctions and monitored two times in a day (morning \& evening) on four hourly basis during summer (May 2008). Sampling points are shown in Figure 1 [15] and latitude and longitude of respective points are reported in Table 1.

The sampling for particulate matter was carried out along the lateral highway connected to NH-202. It is a two way road of width 60 feet on each side with high traffic density comprising mostly 2 wheeler, 3 wheeler, 4 wheeler and heavy vehicles. The average traffic movement along the lateral highway is shown in Table 2.

\section{Materials and Methods}

The particle size distribution was analysed using Personal Sioutas Cascade Impactor Sampler (PCIS) along with Ley Land Legacy pump, which is capable of maintaining a constant flow rate of $9 \mathrm{~L} / \mathrm{min}$ was used for sampling. Sampling was carried out at five traffic junctions along the lateral highway connected to major national high ways passing through Hyderabad. Sampling was carried out on 4 hrly basis during May 2008. During sampling period simultaneously traffic data collected and reported along the highway.

The PCIS is a miniatured cascade impactor consisting of four impaction stages and an after filter that allows the separation and collection of air borne particles in five size ranges [16]. Cut size of particle $D_{P 50}$ at each stage is as follows:

$\begin{array}{llll}2.5 & \mu \mathrm{m} . & - & \text { Stage A } \\ 1.0 & \mu \mathrm{m} & - & \text { Stage B } \\ 0.5 & \mu \mathrm{m} & - & \text { Stage C } \\ 0.25 & \mu \mathrm{m} & - & \text { Stage D }\end{array}$

Less than $0.25 \mu \mathrm{m} \quad-\quad$ Backup filter (After Filter)

That is Particles collected at stage A, B, C \& D are 2.5 - $10 \mu \mathrm{m}, 1.0-2.5 \mu \mathrm{m}, 0.5-1.0 \mu \mathrm{m}$ and $0.25-0.5 \mu \mathrm{m}$ respectively.

Particles above each cut size are collected on a $25 \mathrm{~mm}$ PTFE filter in the respective stage. Stage ' $A$ ' designed to collect particles less than $10 \mu \mathrm{m}$ size only i.e., size of particulates $2.5 \mu \mathrm{m}$ to $10 \mu \mathrm{m}$. Particles below $0.25 \mu \mathrm{m}$ collected on last stage of $37 \mathrm{~mm}$ PTFE after filter. Particle weight on the filter represents the percent less than 


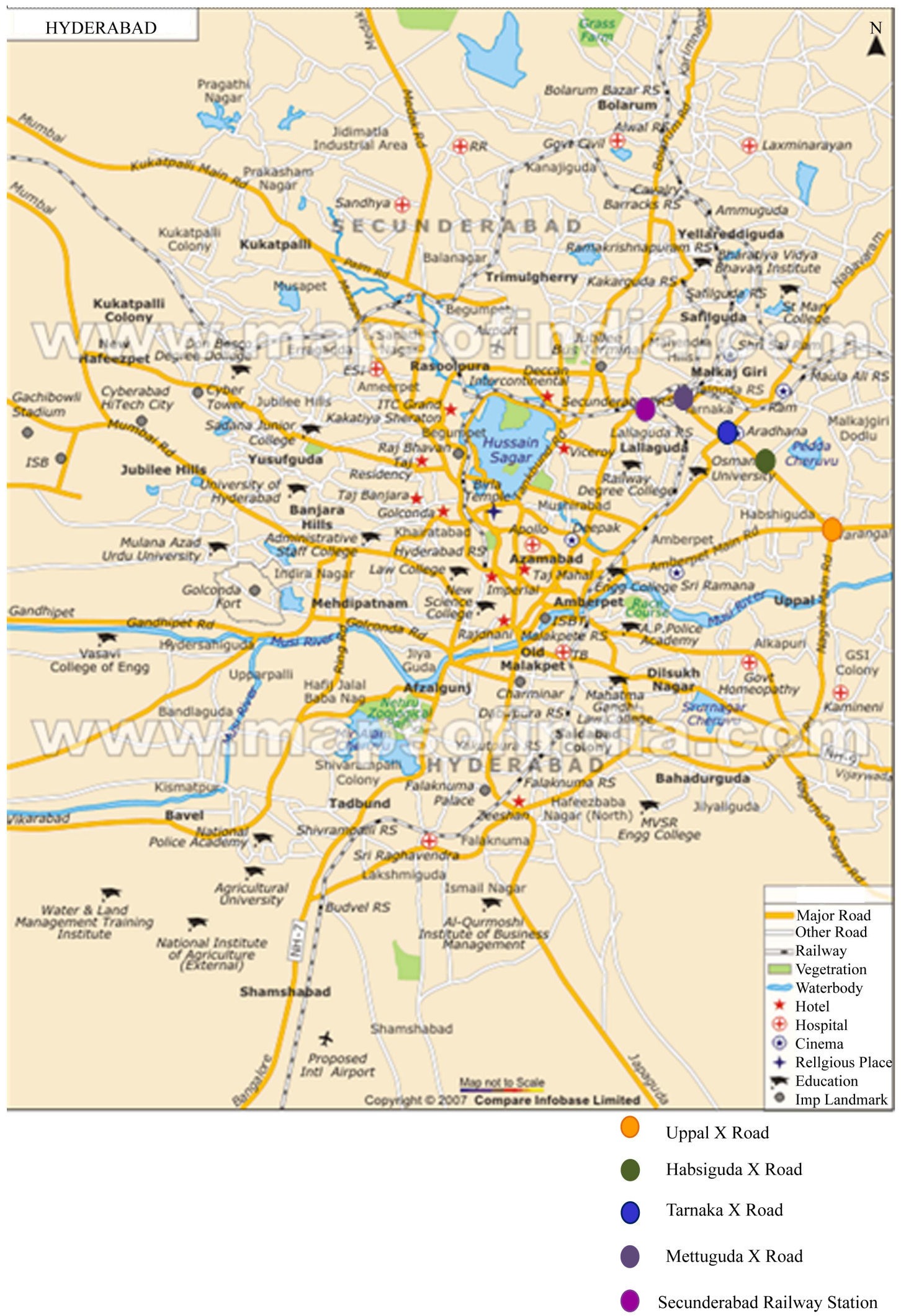

Figure 1. Particulate Matter 2.5 Monitoring Locations along Lateral Highway. 
Table 1. Location of the Stations.

\begin{tabular}{cccc}
\hline S. No. & Name of the Site & Latitude & Longitude \\
\hline 1 & $\begin{array}{c}\text { Secunderabad Railway } \\
\text { Station }\end{array}$ & $17^{\circ} 26^{\prime} 04^{\prime \prime} \mathrm{N}$ & $78^{\circ} 30^{\prime} 06^{\prime} \mathrm{E}$ \\
2 & Mettuguda X Road & $17^{\circ} 26^{\prime} 11^{\prime \prime} \mathrm{N}$ & $78^{\circ} 31^{\prime} 08^{\prime \prime} \mathrm{E}$ \\
3 & Tarnaka X Road & $17^{\circ} 25^{\prime} 37^{\prime \prime} \mathrm{N}$ & $78^{\circ} 31^{\prime} 52^{\prime \prime} \mathrm{E}$ \\
4 & Habsiguda X Road & $17^{\circ} 25^{\prime} 09^{\prime \prime} \mathrm{N}$ & $78^{\circ} 32^{\prime} 28^{\prime \prime} \mathrm{E}$ \\
5 & Uppal X Road & $17^{\circ} 24^{\prime} 06^{\prime \prime} \mathrm{N}$ & $78^{\circ} 33^{\prime} 36^{\prime \prime} \mathrm{E}$ \\
\hline
\end{tabular}

Table 2. Average traffic movement along the lateral highway.

\begin{tabular}{ccc}
\hline Vehicles & $\begin{array}{c}\text { Morning } \\
(\mathbf{9}-\mathbf{1 2} \text { hrs })\end{array}$ & $\begin{array}{c}\text { Afternoon } \\
(\mathbf{1 2}-\mathbf{1 6} \text { hrs })\end{array}$ \\
\hline 2 wheeler & 3592 & 3025 \\
3 wheeler & 1004 & 1439 \\
4 wheeler & 1992 & 2611 \\
Heavy vehicles & 664 & 1038 \\
\hline
\end{tabular}

the cut size of previous stage.

Size-fractionated samples analysed gravimetrically. PTFE filters were equilibrated in Desiccators containing calcium Chloride (fused) for $24 \mathrm{hr}$ before and after sample collection and weighed on pre-calibrated Sartorious balance CP2250 of $0.01 \mathrm{mg}$ sensitivity. The values are reported cumulative weight $\%$ less than the $\mathrm{D}_{\mathrm{P}, 50}$ for each stage and reported respective concentration in $\mu \mathrm{g} / \mathrm{m}^{3}$. The reported values for Secunderabad, Mettuguda, Tar- naka, Habsiguda and Uppal x roads are given in Table 3, Table 4, Table 5, Table 6 and Table 7 respectively.

\section{Results and Discussion}

Location of sampling sites shown in Figure 1 (Table 1) indicates that distance between two adjacent sites is not more than $2 \mathrm{~km}$, except site no. 5 , which is around $3 \mathrm{~km}$ away from site No. 4. Activity wise site 5 represents mainly traffic, whereas other sites represents apart from traffic commercial activities exist to some extent. Traffic information (Table 2) indicates that traffic movement is higher in afternoon hours when compare with morning hours except two wheelers.

Size fractionation of airborne particulate values reported from Tables 3 to 7. It indicates that high values of $\mathrm{PM}_{10}$ observed at site no. 2 (Mettuguda) $303 \mu \mathrm{g} / \mathrm{m}^{3}$ during morning hours and at site no. 1 (Secunderabad) 550 $\mu \mathrm{g} / \mathrm{m}^{3}$ during afternoon hours. Corresponding $\mathrm{PM}_{2.5}$ values are very high at these sites 1 and 2 which are 187 $\mu \mathrm{g} / \mathrm{m}^{3}$ and $294 \mu \mathrm{g} / \mathrm{m}^{3}$ respectively; it may be due to localized activities. At the remaining sites $\mathrm{PM}_{10}$ values are varying from $103 \mu \mathrm{g} / \mathrm{m}^{3}$ to $210 \mu \mathrm{g} / \mathrm{m}^{3}$ irrespective of morning and afternoon hours and $\mathrm{PM}_{2.5}$ concentrations are between $42 \mu \mathrm{g} / \mathrm{m}^{3}$ and $109 \mu \mathrm{g} / \mathrm{m}^{3}$.

Observed values of $\mathrm{PM}_{10}$ and $\mathrm{PM}_{2.5}$ at five sites indicate that maximum of $\mathrm{PM}_{10}$ and $\mathrm{PM}_{2.5}$ at Mettuguda $\mathrm{x}$ Road is 550 and $294 \mu \mathrm{g} / \mathrm{m}^{3}$ respectively, whereas minimum of $\mathrm{PM}_{10}$ and $\mathrm{PM}_{2.5}$ is $103 \mu \mathrm{g} / \mathrm{m}^{3}$ and $42 \mu \mathrm{g} / \mathrm{m}^{3}$ at Tarnaka $\mathrm{x}$ road. The higher values may be due to local

Table 3. $\mathbf{P M}_{2.5}$ Concentration at Secunderabad (Site no. 1).

\begin{tabular}{|c|c|c|c|c|}
\hline \multirow{2}{*}{$\begin{array}{l}\text { Particle cut size less than } \\
\qquad D_{\mathrm{P}, 50}\end{array}$} & \multicolumn{2}{|c|}{ Morning } & \multicolumn{2}{|c|}{ Afternoon } \\
\hline & Concentration in $\mu \mathrm{g} / \mathrm{m}^{3}$ & $\begin{array}{c}\text { Cumulative \% Weight } \\
\text { Less than Dp }\end{array}$ & Concentration in $\mu \mathrm{g} / \mathrm{m}^{3}$ & $\begin{array}{c}\text { Cumulative } \% \text { Weight } \\
\text { Less than Dp }\end{array}$ \\
\hline 0.25 & 46 & 24 & 97 & 32 \\
\hline 0.5 & 69 & 36 & 136 & 45 \\
\hline 1.0 & 84 & 43 & 144 & 48 \\
\hline 2.5 & 102 & 53 & 187 & 62 \\
\hline 10 & 194 & 100 & 303 & 100 \\
\hline
\end{tabular}

Table 4. $\mathbf{P M}_{2.5}$ Concentration at Mettuguda X Road (Site no. 2).

\begin{tabular}{|c|c|c|c|c|}
\hline \multirow{2}{*}{$\begin{array}{l}\text { Particle cut size less than } \\
\qquad D_{P, 50}\end{array}$} & \multicolumn{2}{|c|}{ Morning } & \multicolumn{2}{|c|}{ Afternoon } \\
\hline & Concentration in $\mu \mathrm{g} / \mathrm{m}^{3}$ & $\begin{array}{l}\text { Cumulative } \% \text { Weight } \\
\text { Less than Dp }\end{array}$ & Concentration in $\mu \mathrm{g} / \mathrm{m}^{3}$ & $\begin{array}{c}\text { Cumulative \% Weight } \\
\text { Less than } \mathrm{Dp}\end{array}$ \\
\hline 0.25 & 93 & 17 & 50 & 26 \\
\hline 0.5 & 124 & 23 & 73 & 38 \\
\hline 1.0 & 174 & 32 & 88 & 46 \\
\hline 2.5 & 294 & 54 & 119 & 62 \\
\hline 10 & 550 & 100 & 193 & 100 \\
\hline
\end{tabular}


Table 5. $\mathbf{P M}_{2.5}$ Concentration at Tarnaka X Road (Site no. 3).

\begin{tabular}{|c|c|c|c|c|}
\hline \multirow{2}{*}{$\begin{array}{l}\text { Particle cut size less than } \\
\qquad D_{P, 50}\end{array}$} & \multicolumn{2}{|c|}{ Morning } & \multicolumn{2}{|c|}{ Afternoon } \\
\hline & $\begin{array}{c}\text { Concentration in } \\
\mu \mathrm{g} / \mathrm{m}^{3}\end{array}$ & $\begin{array}{l}\text { Cumulative } \% \text { Weight } \\
\text { Less than Dp }\end{array}$ & $\begin{array}{c}\text { Concentration in } \\
\mu \mathrm{g} / \mathrm{m}^{3}\end{array}$ & $\begin{array}{c}\text { Cumulative \% Weight } \\
\text { Less than Dp }\end{array}$ \\
\hline 0.25 & 23 & 22 & 35 & 23 \\
\hline 0.5 & 34 & 33 & 62 & 40 \\
\hline 1.0 & 38 & 37 & 74 & 48 \\
\hline 2.5 & 42 & 41 & 97 & 63 \\
\hline 10 & 103 & 100 & 155 & 100 \\
\hline
\end{tabular}

Table 6. $\mathrm{PM}_{2.5}$ Concentration at Habsiguda X Road (Site no. 4).

\begin{tabular}{|c|c|c|c|c|}
\hline \multirow{2}{*}{$\begin{array}{l}\text { Particle cut size less than } \\
\qquad D_{P, 50}\end{array}$} & \multicolumn{2}{|c|}{ Morning } & \multicolumn{2}{|c|}{ Afternoon } \\
\hline & Concentration in $\mu \mathrm{g} / \mathrm{m}^{3}$ & $\begin{array}{c}\text { Cumulative \% Weight } \\
\text { Less than Dp }\end{array}$ & Concentration in $\mu \mathrm{g} / \mathrm{m}^{3}$ & $\begin{array}{c}\text { Cumulative } \% \text { Weight } \\
\text { Less than Dp }\end{array}$ \\
\hline 0.25 & 38 & 18 & 31 & 21 \\
\hline 0.5 & 52 & 25 & 40 & 27 \\
\hline 1.0 & 80 & 38 & 55 & 37 \\
\hline 2.5 & 109 & 52 & 80 & 54 \\
\hline 10 & 210 & 100 & 148 & 100 \\
\hline
\end{tabular}

Table 7. $\mathrm{PM}_{2.5}$ Concentration at Uppal X Road (Site no. 5).

\begin{tabular}{|c|c|c|c|c|}
\hline \multirow{2}{*}{$\begin{array}{l}\text { Particle cut size less than } \\
\qquad D_{P, 50}\end{array}$} & \multicolumn{2}{|c|}{ Morning } & \multicolumn{2}{|c|}{ Afternoon } \\
\hline & Concentration in $\mu \mathrm{g} / \mathrm{m}^{3}$ & $\begin{array}{c}\text { Cumulative \% Weight } \\
\text { Less than Dp }\end{array}$ & Concentration in $\mu \mathrm{g} / \mathrm{m}^{3}$ & $\begin{array}{c}\text { Cumulative } \% \text { Weight } \\
\text { Less than } \mathrm{Dp}\end{array}$ \\
\hline 0.25 & 4 & 3 & 23 & 16 \\
\hline 0.5 & 4 & 3 & 27 & 19 \\
\hline 1.0 & 35 & 23 & 27 & 19 \\
\hline 2.5 & 54 & 35 & 46 & 32 \\
\hline 10 & 157 & 100 & 142 & 100 \\
\hline
\end{tabular}

activities i.e., road widening work was in progress during study period and the values are very uncertain. However at site 5 (Uppal X Road), $\mathrm{PM}_{2.5}$ levels are within the limits when compare with CPCB prescribed standards (60 $\mu \mathrm{g} / \mathrm{m}^{3}$ ) throughout day. It may be due to free flow of traffic when compare with other sites.

Study also indicates that percentage weight of $\mathrm{PM}_{2.5}$ varies from $32 \%$ to $63 \%$ in total RSPM sample $\mathrm{PM}_{10}$. However percentage of $\mathrm{PM}_{2.5}$ is varying in total $\mathrm{PM}_{10}$ (RSPM) and also not showing any tendency, being apart from vehicular movement, local activities also exist. Existing study indicates most of the $\mathrm{PM}_{2.5}$ values are $60 \%$ of $\mathrm{PM}_{10}$ values. $\mathrm{PM}_{10}$ values are exceeding CPCB prescribed limit $100 \mu \mathrm{g} / \mathrm{m}^{3}$ (24 hrly average) at all the sites. Whereas very fine particulates concentration $\leq 0.25 \mu \mathrm{m}$ is vary from 4 to $93 \mu \mathrm{g} / \mathrm{m}^{3}$.

$\mathrm{PM}_{0.1}$ values are considered as ultrafine particles and also a part of $\mathrm{PM}_{0.25}$ particulate concentration. Results indicate that maximum value of $\mathrm{PM}_{0.25}$ is $97 \mu \mathrm{g} / \mathrm{m}^{3}$ at site 1 and minimum value is $4 \mu \mathrm{g} / \mathrm{m}^{3}$ at site 5 . Percentage of $\mathrm{PM}_{0.25}$ in total $\mathrm{PM}_{10}$ is minimum $3 \mu \mathrm{g} / \mathrm{m}^{3}$ at site 5 and is maximum $32 \mu \mathrm{g} / \mathrm{m}^{3}$ at site 1 . Indoor combustion sources such as cooking, wood burning and candles can contribute to ultrafine exposure. Internal combustion is a prominent source of ultrafine particles [17].

It is observed that along the lateral highway presence of $\mathrm{PM}_{10}$ and $\mathrm{PM}_{2.5}$ are very high. It is certainly effect road side commuters, business men and traffic police who are on duty. The higher values at Mettuguda is mainly due to construction activities, whereas at Secunderabad is due to bus bay including higher vehicle movement, being located near by railway station. Results indicate that percentage of fine particulate concentration values are more at site $1 \& 2$, site $3 \& 4$ reflects mainly due 
to traffic movement apart from local activities. At all the sites $\mathrm{PM}_{10}$ values are exceeding limits when compare with prescribed standards of CPCB $\left(100 \mu \mathrm{g} / \mathrm{m}^{3}\right)$ on 24 hrly basis, whereas $\mathrm{PM}_{2.5}$ also exceeding the limits $(60$ $\mu \mathrm{g} / \mathrm{m}^{3}$ ) except at site no. 5 .

\section{Conclusions}

It is concluded that respirable dust levels $\left(\leq \mathrm{PM}_{10}\right)$ along the section of lateral highway exceeding the limits in almost all the sites. $\mathrm{PM}_{2.5}$ has been considered as very fine particles also exceeding the limits except in few cases when compared with prescribed limits. It clearly indicates that free movement of transportation directly reflects presence of fine particles of respirable fraction. Concentration of very fine particulate $(<0.25 \mu \mathrm{m})$ is higher at site no. $1 \& 2$ when compare with site $3,4 \& 5$ and percentage weight fraction at site No. 5 is less when compare with other sites.

Presence of fine and very fine particles in ambient air penetrate deep into the respiratory system, which are very high at Secunderabad and Mettuguda traffic junctions. It causes health effect on road side petty business people and also reflects on indoor air quality of closed residential area including on traffic police on duty. Hence special attention to be given for free flow of traffic as well as maintenance of roads should carry out on late night of the day.

\section{REFERENCES}

[1] P. J. Sturm, et al., "Road Side Measurement of Particulate Matter Size Distribution," Atmospheric Environment, Vol. 37, No. 37, 2003, pp. 5273-5281. doi:10.1016/j.atmosenv.2003.05.006

[2] "What Is PM2.5?" 4 July 2008. http://www.epa.gov/region4/sesd/pm25/p2.htm\#5

[3] Animeshkumar, K. M. Phadke, D. S. Tajne, A. L. Aggarwal and M. Z. Hassan, "A Sampling Technique for Monitoring the Respirable Suspended Particulates in Air," Indian Journal of Environmental Health, Vol. 39 No. 4, 1997, pp. 299-307.
[4] M. K. Reddy, "Assessment of Particle Size from Selected Industrial Emission Sources," Indian Journal of Environmental Health, Vol. 29, No. 1, 1987, pp. 39-44.

[5] "Where does PM2.5 Come from?" 4 July 2008. http://www.health.state.ny.us/environmental/indoors/air/p $\mathrm{mq}$ a.htm

[6] WHO, "WHO Guide Lines for Air Quality," 1999.

[7] U.S Department of Labor, Occupational Safety \& Health Administration, Chapter 1. http://www.OSHA.gov

[8] R. Agarwal, R. Prasad and A. Alabh, "Need for a New Fine Particulate Standard for Ambient Air Quality," Indian Journal of Air Pollution Control, Vol. 2, No. 1, April 2002.

[9] L. Ramakrishna, D. V. S. Murthy and T. Swaminathan, "Fine Particulate Matter Profile in Ambient Air of Chennai City," Proceedings of Indo-US Workshop on Modeling of Transport of Air Pollutants, 11-13 November 2003.

[10] R. Kumar and A. E. Joseph, "Air Pollution Concentrations of $\mathrm{PM}_{2.5}, \mathrm{PM}_{10}$ and $\mathrm{NO}_{\mathrm{x}}$ at Ambient and Kerbsite and Their Correlation in Metro City-Mumbai," Environmental Monitoring and Assessment, Vol. 119, No. 1-3, 2006, pp. 191-199. doi:10.1007/s10661-005-9022-7

[11] USEPA, "Review of the National Ambient Air Quality Standards for Particulate Matter, Policy Assessment of Scientific and Technical Information-June 2001,"

[12] "National Ambient Air Quality Standards," 14 June 2011. http://cpcb.nic.in/National_Ambient_Air_Quality_Standa rds.php

[13] "PM Standard Revision -2006 Sub-Head: Back Ground," 14 June 2011. http://www.epa.gov/oar/particlepollution/naaqsrev2006.ht $\mathrm{ml}$

[14] "Hyderabad census 2011 Highlights," 5 June 2011. http.//www.census2011.com/

[15] "Hyderabad Map," 4 July 2008. http.//www.mapsofindia.com

[16] M. Singh, C. Misra and C. Sioutas, "Field Evaluation of a Personal Cascade Impactor," Atmospheric Environment, Vol. 37, 2003, pp. 4781-4793.

[17] AIR Resource Board, "Current Issues in Ultrafine Particle Research: The ARB's Health and Exposure Research Program," California EPA, 20 July 2006. 